\title{
LIN28A polymorphisms and hepatoblastoma susceptibility in Chinese children
}

\author{
Zhonghua Yang1, Yuyao Deng'2, Keren Zhang1, Yuzuo Bai1, Jinhong Zhu'3 , Jiao Zhang', Jiwen Cheng5 ${ }^{5}$ Li \\ $\mathrm{Li}^{6}$, Jing $\mathrm{He}^{7 \bowtie}$, Weilin Wang ${ }^{1 凶}$ \\ 1. Department of Pediatric Surgery, Shengiing Hospital of China Medical University, Shenyang 110004, Liaoning, China. \\ 2. Department of Clinical Medicine, The Fourth Affiliated Hospital of China Medical University, Shenyang 110001, Liaoning, China. \\ 3. Department of Clinical Laboratory, Biobank, Harbin Medical University Cancer Hospital, Harbin 150040, Heilongjiang, China. \\ 4. Department of Pediatric Surgery, the First Affiliated Hospital of Zhengzhou University, Zhengzhou 450052, Henan, China. \\ 5. Department of Pediatric Surgery, the Second Affiliated Hospital of Xi'an Jiaotong University, Xi'an 710004, Shaanxi, China. \\ 6. Kunming Key Laboratory of Children Infection and Immunity, Yunnan Key Laboratory of Children's Major Disease Research, Yunnan Institute of \\ Pediatrics Research, Yunnan Medical Center for Pediatric Diseases, Kunming Children's Hospital, Kunming 650228, Yunnan, China. \\ 7. Department of Pediatric Surgery, Guangzhou Institute of Pediatrics, Guangdong Provincial Key Laboratory of Research in Structural Birth Defect Disease, \\ Guangzhou Women and Children's Medical Center, Guangzhou Medical University, Guangzhou 510623, Guangdong, China.
}

$\square$ Corresponding author: Weilin Wang, Department of Pediatric Surgery, Shengjing Hospital of China Medical University, 36 Sanhao Street, Heping District, Shenyang110004, Liaoning, China, Email: wangwl@sj-hospital.org; or Jing He, Department of Pediatric Surgery, Guangzhou Institute of Pediatrics, Guangdong Provincial Key Laboratory of Research in Structural Birth Defect Disease, Guangzhou Women and Children's Medical Center, Guangzhou Medical University, 9 Jinsui Road, Guangzhou 510623, Guangdong, China, Email: hejing198374@gmail.com.

(c) The author(s). This is an open access article distributed under the terms of the Creative Commons Attribution License (https://creativecommons.org/licenses/by/4.0/). See http://ivyspring.com/terms for full terms and conditions.

Received: 2020.08.31; Accepted: 2020.12.07; Published: 2021.01.01

\begin{abstract}
Hepatoblastoma $(\mathrm{HB})$ is the most prevalent primary hepatic cancer in children aged 6 months to 3 years. LIN28A is recurrently mutated in various diseases, and critically involved in tumorigenesis. However, a limited number of studies have examined the involvement of LIN28A polymorphisms in $\mathrm{HB}$ risk. We used the TaqMan assay to genotype four LIN28A polymorphisms (rs3811464 G>A, rs3811463 T>C, rs34787247 G>A, and rs $11247957 \mathrm{G}>\mathrm{A}$ ) in 275 Chinese children with HB and 1018 cancer-free controls from five medical centers in China. Their association with $\mathrm{HB}$ risk was evaluated on the basis of odds ratio $(\mathrm{OR})$ and corresponding $95 \%$ confidence interval $(\mathrm{Cl})$. Overall, no significant associations were found in single locus and combine analysis. Interestingly, in the stratified analysis, we found that subjects with 1-3 risk genotypes were more likely to develop HB in patients $\geq 17$ months of age (adjusted OR=1.76, 95\% $\mathrm{Cl}=1.04-2.98, P=0.034)$. The $\mathrm{rs} 3811464 \mathrm{GA} / \mathrm{AA}$ genotypes were associated with decrease $\mathrm{HB}$ risk in patients with clinical stage III+IV disease (adjusted $O R=0.50,95 \% \mathrm{Cl}=0.26-0.96, P=0.038$ ). Our results suggest that the LIN28A polymorphisms have a weak association with HB susceptibility in the Chinese children. LIN28A rs3811464 G>A may decrease HB risk in stage III+IV patients which need further validations with larger samples and different ethnicities.
\end{abstract}

Key words: Hepatoblastoma, Susceptibility, LIN28A, Polymorphism

\section{Introduction}

Hepatoblastoma $(\mathrm{HB})$ is the most prevalent primary hepatic cancer of embryonic origin [1]. HB frequently exhibits a combination of histological patterns because of repeating stages in liver development [2]. The incidence of HB peaks between the ages of 6 months and 3 years, and HB is more frequently seen in males [3]. Over the last 2-3 decades, due to advances in multimodal treatments including surgical resection and adjuvant chemotherapy, 5-year overall survival rates have achieved as high as $80 \%$ [4]. Meantime, as a result of low-birth-weight infants and the enhanced survival of premature babies, the incidence of $\mathrm{HB}$ appears to be gradually increasing, with about $4 \%$ per year for the period of 1992 to 2004 and a current rate of 1.5 cases/million [5-7]. Furthermore, non-resectable tumors or metastases are associated with a poor prognosis $[4,8]$. To improve prognosis in $\mathrm{HB}$, it is essential to comprehensively 
understand its pathogenesis $[5,9]$.

The most of $\mathrm{HB}$ is sporadic, but there are some familial cases associated with constitutional genetic abnormalities, such as familial adenomatous polyposis, trisomy 18 syndrome and BeckwithWiedemann syndrome (BWS) [10-12]. Interestingly, single nucleotide polymorphisms (SNPs) have been found to be associated with the development and poor outcome of HB. Kim et al. used SNP array for whole-exome sequencing and analyses of genome-wide loss of heterozygosity and copy number in a BWS infant with HB. They found 11p15.5 uniparental disomy and $A P C$ and PALB2 mutations at the germline level, and chromosome $1 \mathrm{q}$ gain and CTNNB1 hotspot mutation at the somatic level [13]. One study used high-density genome-wide SNP microarray analyses and demonstrated that $88 \%$ cases had chromosomal aberrations such as 1q,17q and 11q, among others [14]. A previous study also demonstrated that LINC00673 rs11655237 C>T polymorphism is significantly associated with HB risk and that rs11655237 $\mathrm{T}$ allele carriers are more likely to develop HB [15]. These results suggested that complicated genomic abnormalities may contribute to the pathogenesis of $\mathrm{HB}$.

LIN28 is an RNA-binding protein that was first shown to be a heterochronic gene controlling developmental timing. It is highly expressed during embryogenesis and plays a vital role in cell growth and embryonic development [16]. Moreover, LIN28 inhibits let-7 miRNA biogenesis and blocks pre-let-7 processing in the cytoplasm. It is known that the let-7 miRNA family targets oncogenic genes and downstream signaling pathways, thereby suppressing the progression of cell cycle and oncogenesis. Therefore, LIN28 acts as an oncogene by inhibiting the synthesis of let-7 [17]. Mammals possess two LIN28 homologs, namely LIN28A and LIN28B [18]. LIN28A resides on chromosome 1p36.11, which blocks the biogenesis of all let-7s and promotes tumor growth [19]. The temporal regulation of LIN28A expression at neurulation blocked axial elongation and embryonic growth in mice [20]. The upregulation of LIN28A by Wnt could enhance the implantation potential of human embryo surrogate spheroids [21]. Besides, Chang et al. identified the loss-of-function variant of LIN28A in patients with early-onset Parkinson's disease. They found that correction of the LIN28A variant in the donor patient's human induced pluripotent stem cells-improved behavioral phenotypes in the Parkinson's disease model [22].

Moreover, LIN28A (rs6598964 G>A) has been associated with increased mortality risk in colorectal cancer [23]. In a hospital-based case-control study involving 1004 cases and 1296 controls, rs3811463 and rs6697410 in LIN28 were found to be associated with breast cancer risk [24]. However, the effect of the LIN28A polymorphisms on HB has not been studied. In the present study, we examined whether SNPs in LIN28A biogenesis genes confer HB risk in the Han Chinese population.

\section{Material and methods}

\section{Patients and controls}

In this study, we enrolled 275 cases with newly histopathologically diagnosed HB and 1018 non-cancer controls from five medical centers in Guangdong, Henan, Shaanxi, Yunnan and Liaoning provinces (Table S1). The 275 included children were examined and surgically treated in these five medical centers, diagnosed pathologically as $\mathrm{HB}$, and finally staged, excluding $\mathrm{HB}$ cases that were examined only and did not undergo surgery, or underwent puncture biopsy only. Non-cancer controls were frequencymatched on age and sex were recruited from the same residing area as cases. Included patients provided their necessary written informed consent and trained interviewers collected their demographic information. The complete criterion for selecting participants was described previously $[25,26]$. Approval for this study was obtained from the ethics committee of each participating hospital. The study protocol was complied with ethical guidelines.

\section{SNP selection and genotyping}

Four LIN28A polymorphisms (rs3811464 G>A, rs3811463 T>C, rs34787247 $\mathrm{G}>\mathrm{A}$, and rs11247957 $\mathrm{G}>\mathrm{A}$ ) were identified through the dbSNP database (http://www.ncbi.nlm.nih.gov/SNP) and SNPinfo online software (https://snpinfo.niehs.nih.gov/ snpinfo/snpfunc.html) as we described previously $[27,28]$. Then the DNA samples were further genotyped using a standard commercial TaqMan real-time PCR kit [29]. About $10 \%$ of the samples were randomly selected and re-genotyped for quality control. We obtained $100 \%$ agreement for the quality control samples.

\section{Statistical analysis}

We used $\chi^{2}$ test to evaluate the difference in the distribution of characteristics, risk factor, and genotypes of LIN28A SNPs between cases and controls. The goodness-of-fit $\chi^{2}$ test was used to check if the frequency distributions of SNP genotypes were in accordance with Hardy-Weinberg equilibrium (HWE) in controls. We performed unconditional univariate and multivariate logistic regression analyses to determine the strength of the association between the selected polymorphisms and risk of $\mathrm{HB}$ through the odds ratios (ORs) and 95\% confidence 
intervals (CIs). Adjustment for age and sex was performed in multivariate analysis. We also carried out stratification analysis based on age, sex, and clinical stages. $P<0.05$ was considered as statistically significant. All statistical analyses were two-sided and carried out using SAS software (version 9.1; SAS Institute, Cary, NC, USA).

\section{Results}

\section{Relationship between LIN28A SNPs and HB susceptibility}

Genotyping was successed in $275 \mathrm{HB}$ cases and 1018 controls. All the four SNPs were in accordance with HWE in controls (rs3811464 G>A, $P=0.165$; rs3811463 T>C, $P=0.823$; rs34787247 G>A, $P=0.193$; and rs11247957 G>A, $P=0.622)$. No significant association was found between LIN28A polymorphisms and HB susceptibility in either single locus or combined analysis (Table 1).

\section{Stratification analysis of association between LIN28A polymorphisms and $\mathrm{HB}$ risk}

In the stratification analysis by age, sex and clinical stages (Table 2), we found significant association with the rs3811464 polymorphism (GA/AA vs. GG: adjusted OR=0.50, 95\% $\mathrm{CI}=0.26-0.96$, $P=0.038$ ) in patients with clinical stages III+IV. Regarding the combined analysis, we found that the 1-3 risk genotypes carriers were at significantly higher HB risk in patients $\geq 17$ months of age (adjusted $\mathrm{OR}=1.76,95 \% \mathrm{CI}=1.04-2.98, P=0.034)$.

Table 1. Association of LIN28A polymorphisms with hepatoblastoma susceptibility

\begin{tabular}{|c|c|c|c|c|c|c|c|}
\hline Genotype & $\begin{array}{l}\text { Cases } \\
(N=275)\end{array}$ & $\begin{array}{l}\text { Controls } \\
(\mathrm{N}=1018)\end{array}$ & $P$ a & $\begin{array}{l}\text { Crude OR } \\
(95 \% \mathrm{CI})\end{array}$ & $P$ & $\begin{array}{l}\text { Adjusted OR } \\
(95 \% \text { CI) b }\end{array}$ & $P$ b \\
\hline \multicolumn{8}{|c|}{ rs3811464 G>A (HWE=0.165) } \\
\hline GG & $208(75.64)$ & $744(73.08)$ & & 1.00 & & 1.00 & \\
\hline GA & $61(22.18)$ & $246(24.17)$ & & $0.89(0.64-1.22)$ & 0.462 & $0.89(0.64-1.22)$ & 0.456 \\
\hline $\mathrm{AA}$ & $6(2.18)$ & $28(2.75)$ & & $0.77(0.31-1.88)$ & 0.560 & $0.77(0.32-1.89)$ & 0.573 \\
\hline Additive & & & 0.367 & $0.88(0.67-1.16)$ & 0.367 & $0.88(0.67-1.16)$ & 0.368 \\
\hline Dominant & $67(24.36)$ & $274(26.92)$ & 0.394 & $0.88(0.64-1.19)$ & 0.394 & $0.87(0.64-1.19)$ & 0.392 \\
\hline Recessive & $269(97.82)$ & $990(97.25)$ & 0.601 & $0.79(0.32-1.92)$ & 0.602 & $0.80(0.33-1.94)$ & 0.616 \\
\hline \multicolumn{8}{|c|}{ rs3811463 $\mathrm{T}>\mathrm{C}(\mathrm{HWE}=0.823)$} \\
\hline $\mathrm{TT}$ & $203(73.82)$ & $741(72.79)$ & & 1.00 & & 1.00 & \\
\hline TC & $64(23.27)$ & $254(24.95)$ & & $0.92(0.67-1.26)$ & 0.603 & $0.92(0.67-1.26)$ & 0.613 \\
\hline $\mathrm{CC}$ & $8(2.91)$ & $23(2.26)$ & & $1.27(0.56-2.88)$ & 0.568 & $1.28(0.56-2.91)$ & 0.553 \\
\hline Additive & & & 0.912 & $0.99(0.76-1.28)$ & 0.913 & $0.99(0.76-1.29)$ & 0.931 \\
\hline Dominant & $72(26.18)$ & $277(27.21)$ & 0.733 & $0.95(0.70-1.28)$ & 0.733 & $0.95(0.70-1.29)$ & 0.748 \\
\hline Recessive & $267(97.09)$ & $995(97.74)$ & 0.532 & $1.30(0.57-2.93)$ & 0.533 & $1.31(0.58-2.96)$ & 0.520 \\
\hline \multicolumn{8}{|c|}{ rs34787247 G>A (HWE=0.193) } \\
\hline GG & $213(77.45)$ & $793(77.90)$ & & 1.00 & & 1.00 & \\
\hline GA & $55(20.00)$ & $206(20.24)$ & & $0.99(0.71-1.39)$ & 0.972 & $0.99(0.71-1.38)$ & 0.958 \\
\hline AA & $7(2.55)$ & $19(1.87)$ & & $1.37(0.57-3.31)$ & 0.481 & $1.38(0.57-3.33)$ & 0.474 \\
\hline Additive & & & 0.727 & $1.05(0.80-1.39)$ & 0.727 & $1.05(0.79-1.39)$ & 0.733 \\
\hline Dominant & $62(22.55)$ & $225(22.10)$ & 0.875 & $1.03(0.75-1.41)$ & 0.875 & $1.02(0.74-1.41)$ & 0.886 \\
\hline Recessive & $268(97.45)$ & $999(98.13)$ & 0.477 & $1.37(0.57-3.30)$ & 0.478 & $1.38(0.58-3.32)$ & 0.470 \\
\hline \multicolumn{8}{|c|}{ rs11247957 G>A (HWE=0.622) } \\
\hline GG & $265(96.36)$ & $987(96.95)$ & & 1.00 & & 1.00 & \\
\hline GA & $10(3.64)$ & $31(3.05)$ & & $1.20(0.58-2.48)$ & 0.620 & $1.22(0.59-2.52)$ & 0.593 \\
\hline $\mathrm{AA}$ & $0(0.00)$ & $0(0.00)$ & & / & / & / & / \\
\hline Additive & & & 0.620 & $1.20(0.58-2.48)$ & 0.620 & $1.22(0.59-2.52)$ & 0.593 \\
\hline Dominant & $10(3.64)$ & $31(3.05)$ & 0.620 & $1.20(0.58-2.48)$ & 0.620 & $1.22(0.59-2.52)$ & 0.593 \\
\hline \multicolumn{8}{|c|}{ Risk genotypes c } \\
\hline 0 & $55(20.00)$ & $239(23.48)$ & 0.175 & 1.00 & & 1.00 & \\
\hline 1 & $207(75.27)$ & 743 (72.99) & & $1.21(0.87-1.69)$ & 0.258 & $1.21(0.87-1.69)$ & 0.251 \\
\hline 2 & $13(4.73)$ & $34(3.34)$ & & $1.66(0.82-3.36)$ & 0.157 & $1.67(0.83-3.37)$ & 0.154 \\
\hline 3 & $0(0.00)$ & $2(0.20)$ & & / & / & / & / \\
\hline 0 & $55(20.00)$ & $239(23.48)$ & & 1.00 & & 1.00 & \\
\hline $1-3$ & $220(80.00)$ & 779 (76.52) & 0.222 & $1.23(0.88-1.71)$ & 0.223 & $1.23(0.89-1.71)$ & 0.216 \\
\hline
\end{tabular}

OR: odds ratio; CI: confidence interval; HWE: Hardy-Weinberg equilibrium.

${ }^{\text {a }} \chi^{2}$ test for genotype distributions between hepatoblastoma patients and cancer-free controls.

$\mathrm{b}$ Adjusted for age and gender.

c Risk genotypes were rs3811464 GG, rs3811463 CC, rs34787247 AA, and rs11247957 GA. 
Table 2. Stratification analysis of protective genotypes and hepatoblastoma susceptibility

\begin{tabular}{|c|c|c|c|c|c|c|c|c|c|c|c|c|c|c|c|c|}
\hline \multirow[t]{2}{*}{ Variables } & \multicolumn{2}{|c|}{$\begin{array}{l}\text { rs3811464 } \\
\text { (cases/controls) }\end{array}$} & \multirow[t]{2}{*}{$\begin{array}{l}\text { AOR } \\
(95 \% \text { CI })^{a}\end{array}$} & \multirow[t]{2}{*}{$P$ a } & \multicolumn{2}{|c|}{$\begin{array}{l}\text { rs3811463 } \\
\text { (cases/controls) }\end{array}$} & \multirow[t]{2}{*}{$\begin{array}{l}\text { AOR } \\
(95 \% \text { CI })^{a}\end{array}$} & \multirow[t]{2}{*}{$P$ a } & \multicolumn{2}{|c|}{$\begin{array}{l}\text { rs34787247 } \\
\text { (cases/controls) }\end{array}$} & \multirow[t]{2}{*}{$\begin{array}{l}\text { AOR } \\
(95 \% \text { CI) a }\end{array}$} & \multirow[t]{2}{*}{$P$ a } & \multicolumn{2}{|c|}{$\begin{array}{l}\text { Risk genotypes } \\
\text { (cases/controls) }\end{array}$} & \multirow[t]{2}{*}{$\begin{array}{l}\text { AOR } \\
(95 \% \text { CI })^{a}\end{array}$} & \multirow[t]{2}{*}{$P$ a } \\
\hline & GG & GA/AA & & & $\mathrm{TT}$ & $\mathrm{TC} / \mathrm{CC}$ & & & GG & GA/AA & & & 0 & $1-3$ & & \\
\hline \multicolumn{17}{|c|}{ Age (month) } \\
\hline$<17$ & $108 / 336$ & $40 / 123$ & $\begin{array}{l}1.01 \\
(0.67-1.53)\end{array}$ & 0.960 & $107 / 339$ & $41 / 120$ & $\begin{array}{l}1.08 \\
(0.71-1.64)\end{array}$ & 0.710 & $117 / 357$ & $31 / 102$ & $\begin{array}{l}0.93 \\
(0.59-1.47)\end{array}$ & 0.757 & $36 / 107$ & $112 / 352$ & $\begin{array}{l}0.95 \\
(0.61-1.46)\end{array}$ & 0.804 \\
\hline$\geq 17$ & $100 / 408$ & $27 / 151$ & $\begin{array}{l}0.73 \\
(0.46-1.16)\end{array}$ & 0.185 & $96 / 402$ & $31 / 157$ & $\begin{array}{l}0.83 \\
(0.53-1.30)\end{array}$ & 0.420 & $96 / 436$ & $31 / 123$ & $\begin{array}{l}1.15 \\
(0.73-1.80)\end{array}$ & 0.557 & $19 / 132$ & $108 / 427$ & $\begin{array}{l}1.76 \\
(1.04-2.98)\end{array}$ & 0.034 \\
\hline \multicolumn{17}{|l|}{ Gender } \\
\hline Females & $84 / 296$ & $29 / 104$ & $\begin{array}{l}0.97 \\
(0.60-1.57)\end{array}$ & 0.908 & $79 / 302$ & $34 / 98$ & $\begin{array}{l}1.32 \\
(0.83-2.09)\end{array}$ & 0.242 & $87 / 308$ & $26 / 92$ & $\begin{array}{l}1.00 \\
(0.61-1.64)\end{array}$ & 0.991 & $24 / 94$ & $89 / 306$ & $\begin{array}{l}1.15 \\
(0.69-1.91)\end{array}$ & 0.594 \\
\hline Males & $124 / 448$ & $38 / 170$ & $\begin{array}{l}0.81 \\
(0.54-1.21)\end{array}$ & 0.303 & $124 / 439$ & $38 / 179$ & $\begin{array}{l}0.75 \\
(0.50-1.13)\end{array}$ & 0.168 & $126 / 485$ & $36 / 133$ & $\begin{array}{l}1.04 \\
(0.69-1.58)\end{array}$ & 0.847 & $31 / 145$ & $131 / 473$ & $\begin{array}{l}1.30 \\
(0.84-2.00)\end{array}$ & 0.241 \\
\hline \multicolumn{17}{|c|}{ Clinical stages } \\
\hline $\mathrm{I}+\mathrm{II}$ & $104 / 744$ & $38 / 274$ & $\begin{array}{l}1.00 \\
(0.67-1.48)\end{array}$ & 0.982 & $100 / 741$ & $42 / 277$ & $\begin{array}{l}1.13 \\
(0.77-1.67)\end{array}$ & 0.530 & $111 / 793$ & $31 / 225$ & $\begin{array}{l}0.98 \\
(0.64-1.50)\end{array}$ & 0.938 & $29 / 239$ & $113 / 779$ & $\begin{array}{l}1.19 \\
(0.77-1.84)\end{array}$ & 0.422 \\
\hline III+IV & $60 / 744$ & $11 / 274$ & $\begin{array}{l}0.50 \\
(0.26-0.96)\end{array}$ & 0.038 & $58 / 741$ & $13 / 277$ & $\begin{array}{l}0.60 \\
(0.32-1.11)\end{array}$ & 0.106 & $53 / 793$ & $18 / 225$ & $\begin{array}{l}1.20 \\
(0.69-2.09)\end{array}$ & 0.522 & $11 / 239$ & $60 / 779$ & $\begin{array}{l}1.67 \\
(0.87-3.24)\end{array}$ & 0.126 \\
\hline
\end{tabular}

AOR: adjusted odds ratio; CI: confidence interval.

a Adjusted for age and gender, omitting the corresponding stratification factor.

\section{Discussion}

$\mathrm{HB}$ is the most prevalent primary hepatic cancer in children and accounts for around $1 \%$ of all childhood cancers [30, 31]. Currently, the 5-year survival rate remains only $20-30 \%$ in cases with considerable unifocal and distant metastases at diagnosis [1, 32]. A number of studies have reported that $\mathrm{HB}$ is related to genetic syndromes. For instance, $7.5-13.5 \%$ of children with BWS develop embryonal tumors, with the most frequent tumors being $\mathrm{HB}$ and nephroblastoma [31]. Studies have also demonstrated that $\mathrm{Wnt} / \beta$-catenin signaling pathway abnormalities exist in most cases of HB [33]. Elevated expression of hTERT (human telomerase reverse transcriptase) and c-MYC appear to be predictive of a poor prognosis because both of them play crucial roles in the activation of $\mathrm{Wnt} / \beta$-catenin signaling in aggressive phenotypes of HB [34, 35]. With further study of $\mathrm{HB}$ pathogenicity genes, researchers have found that methylation and polymorphism of genes, microRNAs and IncRNAs are also related to the carcinogenesis of HB [15, 36-38]. However, there has been no prior study about the association of LIN28A polymorphisms with HB susceptibility.

There have been many studies underscoring the importance of LIN28A in the regulation of stem cell pluripotency and self-renewal; however, recent investigations have shown abnormal expression of LIN28A in a broad array of tumor types, which is connected to advanced disease and poor prognosis [39]. The findings of various studies have suggested that LIN28A gene polymorphisms play a role in cancer risk. Rao et al. found that LIN28A was a good immunohistochemistry marker for the diagnosis of embryonal tumor with multilayered rosettes [40]. Li et al. showed that the downregulation of LIN28A expression suppressed differentiation and self-renewal of human breast cancer stem cells by inactivating the Wnt pathway in a let-7b-dependent manner [41]. A case-control study at four centers demonstrated that LIN28A gene polymorphisms alter susceptibility to neuroblastoma; it was found that LIN28A SNPs, particularly rs34787247 G>A, could increase neuroblastoma risk [28]. Also, LIN28A rs3811463 $\mathrm{T}>\mathrm{C}$ and rs34787247 $\mathrm{G}>\mathrm{A}$ have been associated with increased risk of Wilms tumor in Chinese children [27].

Our study showed that LIN28A polymorphisms affects $\mathrm{HB}$ susceptibility in a low-penetrating manner. We failed to find any single locos that can modify HB susceptibility. Stratified analysis indicated that rs3811464 GA/AA carriers had reduced risk to develop clinical stages III+IV tumors; the presence of 1-3 risk genotypes was significantly associated with HB risk among children $\geq 17$ months of age. To our knowledge, we are the first group to confirm the association between LIN28A polymorphisms and HB susceptibility. Interestingly, we found that the presence of rs3811464 GA/AA genotypes in LIN28A provided a protective effect for children with clinical stages III+IV HB. Liu et al. studied the association between APEX1 polymorphisms and neuroblastoma risk in Chinese children, and found that the rs1130409 GG genotype significantly reduced the tumor risk in males older than 18 months with 1-3 protective genotypes, and had a lower neuroblastoma risk [42]. The effect of gene polymorphisms on cancer risk may be affected by tumor type, sample sizes, and selection criteria. Therefore, the association between LIN28A polymorphisms and $\mathrm{HB}$ risk should be specified in a particular population.

Our study demonstrated that LIN28A 
polymorphisms were not significantly associated with HB susceptibility. However, LIN28A rs34787247 G>A has been reported to be connected to increased risk of neuroblastoma and LIN28A rs3811463 $\mathrm{T}>\mathrm{C}$ and rs34787247 G>A to increased risk of nephroblastoma $[27,28]$. Moreover, a study in East Asia showed that SNPs of LIN28A (rs11247954, rs12728900, rs3811463, rs4274112, rs4659441, rs6598964, and rs6683792) were not significantly associated with breast cancer risk [43]. According to these findings, the effects of LIN28A polymorphisms on cancer susceptibility may be tumor type-specific. Single SNPs have been shown to be insufficient to modify tumor risk, while the occurrence of several SNPs could synergistically play significant roles in carcinogenesis [44].

Although this was the first and largest case-control study to assess the association between LIN28A polymorphisms and HB risk in the Chinese population to date, it cannot represent the entire Chinese population. Moreover, this study did not involve other races of people. Selection bias is an obvious possible confounding factor. Meantime due for phased research results of this study, there was no verification. We need to expand the sample size to further confirm the above results. To better determine the association of LIN28A polymorphisms with susceptibility to $\mathrm{HB}$, further investigations should be designed to consider related factors including environmental background and data on parental diet, lifestyle, and exposure to hazards.

Overall, this study demonstrates that LIN28A SNPs have a weak relationship with HB susceptibility in the Chinese population.

\section{Supplementary Material}

Supplementary table S1.

http://www.jcancer.org/v12p1373s1.pdf

\section{Acknowledgement}

This work was supported by grants from the Science and Technology Project of Guangzhou (No: 201904010046), and Guangdong Provincial Key Laboratory of Research in Structural Birth Defect Disease (No: 2019B030301004).

\section{Data availability statement}

All data were available upon request.

\section{Conflict of interest statement}

The authors declared that the research was conducted in the absence of any commercial or financial relationships that could be construed as a potential conflict of interest.

\section{References}

1. Feng TC, Zai HY, Jiang W, Zhu Q, Jiang B, Yao L, Li XY and Wang ZM. Survival and analysis of prognostic factors for hepatoblastoma: based on SEER database. Ann Transl Med. 2019; 7(20):555.

2. Finegold MJ, Lopez-Terrada DH, Bowen J, Washington MK, Qualman SJ and College of American P. Protocol for the examination of specimens from pediatric patients with hepatoblastoma. Arch Pathol Lab Med. 2007; 131(4):520-529.

3. McCarville MB and Roebuck DJ. Diagnosis and staging of hepatoblastoma: imaging aspects. Pediatr Blood Cancer. 2012; 59(5):793-799.

4. Czauderna P, Lopez-Terrada D, Hiyama E, Haberle B, Malogolowkin MH and Meyers RL. Hepatoblastoma state of the art: pathology, genetics, risk stratification, and chemotherapy. Curr Opin Pediatr. 2014; 26(1):19-28.

5. Linabery AM and Ross JA. Trends in childhood cancer incidence in the U.S. (1992-2004). Cancer. 2008; 112(2):416-432.

6. Allan BJ, Parikh PP, Diaz S, Perez EA, Neville HL and Sola JE. Predictors of survival and incidence of hepatoblastoma in the paediatric population. HPB (Oxford). 2013; 15(10):741-746.

7. Meyers RL, Maibach R, Hiyama E, Haberle B, Krailo M, Rangaswami A, Aronson DC, Malogolowkin MH, Perilongo G, von Schweinitz D, Ansari M, Lopez-Terrada D, Tanaka Y, Alaggio R, Leuschner I, Hishiki T, et al. Risk-stratified staging in paediatric hepatoblastoma: a unified analysis from the Children's Hepatic tumors International Collaboration. Lancet Oncol. 2017; 18(1):122-131.

8. Williams CL, Bunch KJ, Stiller CA, Murphy MF, Botting BJ, Wallace WH, Davies $\mathrm{M}$ and Sutcliffe AG. Cancer risk among children born after assisted conception. N Engl J Med. 2013; 369(19):1819-1827.

9. Rodriguez-Galindo C, Krailo M, Frazier L, Chintagumpala M, Amatruda J, Katzenstein H, Malogolowkin M, Spector L, Pashankar F, Meyers R, Tomlinson G and Committee COGRTD. Children's Oncology Group's 2013 blueprint for research: rare tumors. Pediatr Blood Cancer. 2013; 60(6):1016-1021.

10. Zhang L, Jin $Y$, Zheng $K$, Wang H, Yang S, Lv C, Han W, Yu Y, Yang Y, Geng D, Yang H, Shi T, Guo Y and Ni X. Whole-Genome Sequencing Identifies a Novel Variation of WAS Gene Coordinating With Heterozygous Germline Mutation of APC to Enhance Hepatoblastoma Oncogenesis. Front Genet. 2018; 9:668.

11. Cohen MM, Jr. Beckwith-Wiedemann syndrome: historical, clinicopathological, and etiopathogenetic perspectives. Pediatr Dev Pathol. 2005; 8(3):287-304

12. Thomas D, Pritchard J, Davidson R, McKiernan P, Grundy RG and de Ville de Goyet J. Familial hepatoblastoma and APC gene mutations: renewed call for molecular research. Eur J Cancer. 2003; 39(15):2200-2204.

13. Kim SY, Jung SH, Kim MS, Han MR, Park HC, Jung ES, Lee SH, Lee SH and Chung YJ. Genomic profiles of a hepatoblastoma from a patient with Beckwith-Wiedemann syndrome with uniparental disomy on chromosome 11 p15 and germline mutation of APC and PALB2. Oncotarget. 2017; 8(54):91950-91957.

14. Suzuki M, Kato M, Yuyan C, Takita J, Sanada M, Nannya Y, Yamamoto G, Takahashi A, Ikeda H, Kuwano H, Ogawa S and Hayashi Y. Whole-genome profiling of chromosomal aberrations in hepatoblastoma using high-density single-nucleotide polymorphism genotyping microarrays. Cancer Sci. 2008; 99(3):564-570.

15. Yang T, Li J, Wen Y, Tan T, Yang J, Pan J, Hu C, Yao Y, Zhang J, Xin Y, Li S, Xia $\mathrm{H}, \mathrm{He} \mathrm{J}$ and Zou Y. LINC00673 rs11655237 C>T Polymorphism Impacts Hepatoblastoma Susceptibility in Chinese Children. Front Genet. 2019; 10:506.

16. Ambros V and Horvitz HR. Heterochronic mutants of the nematode Caenorhabditis elegans. Science. 1984; 226(4673):409-416.

17. Sung Y, Jeong J, Kang RJ, Choi M, Park S, Kwon W, Lee J, Jang S, Park SJ, Kim SH, Yi J, Choi SK, Lee MH, Liu K, Dong Z, Ryoo ZY, et al. Lin28a expression protects against streptozotocin-induced beta-cell destruction and prevents diabetes in mice. Cell Biochem Funct. 2019; 37(3):139-147.

18. Shyh-Chang $\mathrm{N}$ and Daley GQ. Lin28: primal regulator of growth and metabolism in stem cells. Cell Stem Cell. 2013; 12(4):395-406.

19. Viswanathan SR, Daley GQ and Gregory RI. Selective blockade of microRNA processing by Lin28. Science. 2008; 320(5872):97-100.

20. Miyazawa H, Muramatsu Y, Makino H, Yamaguchi Y and Miura M. Temporal regulation of Lin28a during mammalian neurulation contributes to neonatal body size control. Dev Dyn. 2019; 248(10):931-941.

21. Li Q, Chiu PCN, Yeung WSB and Liu W. Regulation of human trophoblast surrogate Jeg-3 spheroids implantation potential by Wnt/beta-catenin pathway and lin28a/let-7a axis. Exp Cell Res. 2020; 388(1):111718.

22. Chang MY, Oh B, Choi JE, Sulistio YA, Woo HJ, Jo A, Kim J, Kim EH, Kim SW, Hwang J, Park J, Song JJ, Kwon OC, Henry Kim H, Kim YH, Ko JY, et al. LIN28A loss of function is associated with Parkinson's disease pathogenesis. EMBO J. 2019; 38(24):e101196.

23. Mullany LE, Herrick JS, Wolff RK and Slattery ML Single nucleotide polymorphisms within MicroRNAs, MicroRNA targets, and MicroRNA biogenesis genes and their impact on colorectal cancer survival. Genes Chromosomes Cancer. 2017; 56(4):285-295.

24. Chen AX, Yu KD, Fan L, Li JY, Yang C, Huang AJ and Shao ZM. Germline genetic variants disturbing the Let-7/LIN28 double-negative feedback loop alter breast cancer susceptibility. PLoS Genet. 2011; 7(9):e1002259. 
25. Li L, Zhuo Z, Yang Z, Zhu J, He X, Yang Z, Zhang J, Xin Y, He J and Zhang T. HMGA2 Polymorphisms and Hepatoblastoma Susceptibility: A Five-Center Case-Control Study. Pharmgenomics Pers Med. 2020; 13:51-57.

26. Yang Z, Deng Y, Zhang K, Bai Y, Zhu J, Zhang J, Xin Y, Li L, He J and Wang W. LIN28B gene polymorphisms modify hepatoblastoma susceptibility in Chinese children. J Cancer. 2020; 11(12):3512-3518.

27. Zhuo Z, Fu W, Liu J, Cheng J, Zhou H, Zhang J, Zhu JH, Xia H, Liu G and He J. LIN28A gene polymorphisms confer Wilms tumour susceptibility: A four-centre case-control study. J Cell Mol Med. 2019; 23(10):7105-7110.

28. Hua RX, Zhuo Z, Ge L, Zhu J, Yuan L, Chen C, Liu J, Cheng J, Zhou H, Zhang $\mathrm{J}$, Xia $\mathrm{H}$, Zhang $\mathrm{X}$ and He J. LIN28A gene polymorphisms modify neuroblastoma susceptibility: A four-centre case-control study. J Cell Mol Med. 2020; 24(1):1059-1066.

29. He J, Wang $F$, Zhu J, Zhang R, Yang T, Zou Y and Xia H. Association of potentially functional variants in the XPG gene with neuroblastoma risk in a Chinese population. J Cell Mol Med. 2016; 20(8):1481-1490.

30. Lim IIP, Bondoc AJ, Geller JI and Tiao GM. Hepatoblastoma-The Evolution of Biology, Surgery, and Transplantation. Children (Basel). 2018; 6(1):1.

31. Devi LP, Kumar R, Handique A and Kumar M. Hepatoblastoma--a rare liver tumor with review of literature. J Gastrointest Cancer. 2014; 45 Suppl $1: 261-264$

32. Lake CM, Tiao GM and Bondoc AJ. Surgical management of locally-advanced and metastatic hepatoblastoma. Semin Pediatr Surg. 2019; 28(6):150856.

33. Takayasu $\mathrm{H}$, Horie $\mathrm{H}$, Hiyama E, Matsunaga $T$, Hayashi $\mathrm{Y}$, Watanabe $\mathrm{Y}$, Suita S, Kaneko M, Sasaki F, Hashizume K, Ozaki T, Furuuchi K, Tada M, Ohnuma $\mathrm{N}$ and Nakagawara A. Frequent deletions and mutations of the beta-catenin gene are associated with overexpression of cyclin D1 and fibronectin and poorly differentiated histology in childhood hepatoblastoma. Clin Cancer Res. 2001; 7(4):901-908.

34. Park JI, Venteicher AS, Hong JY, Choi J, Jun S, Shkreli M, Chang W, Meng Z, Cheung P, Ji H, McLaughlin M, Veenstra TD, Nusse R, McCrea PD and Artandi SE. Telomerase modulates Wnt signalling by association with target gene chromatin. Nature. 2009; 460(7251):66-72.

35. Ueda Y, Hiyama E, Kamimatsuse A, Kamei N, Ogura K and Sueda T. Wnt signaling and telomerase activation of hepatoblastoma: correlation with chemosensitivity and surgical resectability. J Pediatr Surg. 2011; 46(12):2221-2227.

36. Liu L, Wang J, Sun G, Wu O, Ma J, Zhang X, Huang N, Bian Z, Gu S, Xu M, Yin $\mathrm{M}$, Sun $\mathrm{F}$ and Pan Q. m(6)A mRNA methylation regulates CTNNB1 to promote the proliferation of hepatoblastoma. Mol Cancer. 2019; 18(1):188.

37. Min Q, Molina L, Li J, Adebayo Michael AO, Russell JO, Preziosi ME, Singh S, Poddar M, Matz-Soja M, Ranganathan S, Bell AW, Gebhardt R, Gaunitz F, Yu J, Tao J and Monga SP. beta-Catenin and Yes-Associated Protein 1 Cooperate in Hepatoblastoma Pathogenesis. Am J Pathol. 2019; 189(5):1091-1104.

38. He J, Guo X, Sun L, Wang N and Bao J. Regulatory network analysis of genes and microRNAs in human hepatoblastoma. Oncol Lett. 2016; 12(5):4099-4106.

39. Viswanathan SR, Powers JT, Einhorn W, Hoshida Y, Ng TL, Toffanin S, O'Sullivan M, Lu J, Phillips LA, Lockhart VL, Shah SP, Tanwar PS, Mermel $\mathrm{CH}$, Beroukhim R, Azam M, Teixeira J, et al. Lin28 promotes transformation and is associated with advanced human malignancies. Nat Genet. 2009; 41(7):843-848

40. Rao S, Rajeswarie RT, Chickabasaviah Yasha T, Nandeesh BN, Arivazhagan A and Santosh V. LIN28A, a sensitive immunohistochemical marker for Embryonal Tumor with Multilayered Rosettes (ETMR), is also positive in a subset of Atypical Teratoid/Rhabdoid Tumor (AT/RT). Childs Nerv Syst. 2017; 33(11):1953-1959.

41. Li X, Liang T, Chen SS, Wang M, Wang R, Li K, Wang JC, Xu CW, Du N, Qin S and Ren $\mathrm{H}$. Matrine suppression of self-renewal was dependent on regulation of LIN28A/Let-7 pathway in breast cancer stem cells. J Cell Biochem. 2020; 121(3):2139-2149.

42. Liu J, Jia W, Hua RX, Zhu J, Zhang J, Yang T, Li P, Xia H, He J and Cheng J. APEX1 Polymorphisms and Neuroblastoma Risk in Chinese Children: A Three-Center Case-Control Study. Oxid Med Cell Longev. 2019; 2019:5736175.

43. Sung H, Zhang B, Choi JY, Long J, Park SK, Yoo KY, Noh DY, Ahn SH, Zheng $\mathrm{W}$ and Kang D. Common genetic variants in the microRNA biogenesis pathway are not associated with breast cancer risk in Asian women. Cancer Epidemiol Biomarkers Prev. 2012; 21(8):1385-1387.

44. Quaye L, Song H, Ramus SJ, Gentry-Maharaj A, Hogdall E, DiCioccio RA, McGuire V, Wu AH, Van Den Berg DJ, Pike MC, Wozniak E, Doherty JA, Rossing MA, Ness RB, Moysich KB, Hogdall C, et al. Tagging single-nucleotide polymorphisms in candidate oncogenes and susceptibility to ovarian cancer. Br J Cancer. 2009; 100(6):993-1001. 